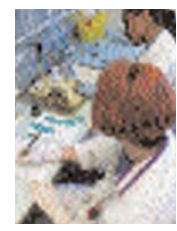

Library launch

Online tumour bank offers easy access to tissue samples p464

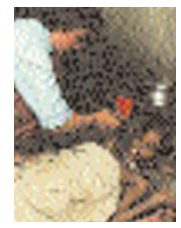

\section{Bedside manner}

Charity tackles developing world's drug needs p465

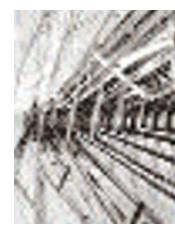

Powered down

Anger as plug is pulled on Vivitron accelerator p466

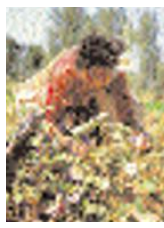

Soft landing

India joins the

transgenic cotton

club

p468

\title{
Papers square up over potential Pulitzer for cancer-centre critics
}

\section{Erika Check, Washington}

Two American newspapers are fighting a messy public battle over a series of articles that criticize one of the most respected cancer centres in the world.

The Seattle Times ran the series, called "Uninformed consent", last March. The series alleged that the Fred Hutchinson Cancer Research Center in Seattle, Washington, failed to tell patients about the true risks of some experimental cancer trials that it ran in the early 1980s. The series concluded that researchers with financial interests in the trials persisted with their research even after they knew it was killing patients. The centre maintains that there was no financial conflict of interest and said in a statement that "the central themes of The Seattle Times' articles are false and unsupportable".

After bagging a slew of awards, "Uninformed consent" is now rumoured to be a finalist for a Pulitzer Prize, the premier award in American journalism. But with the Pulitzer

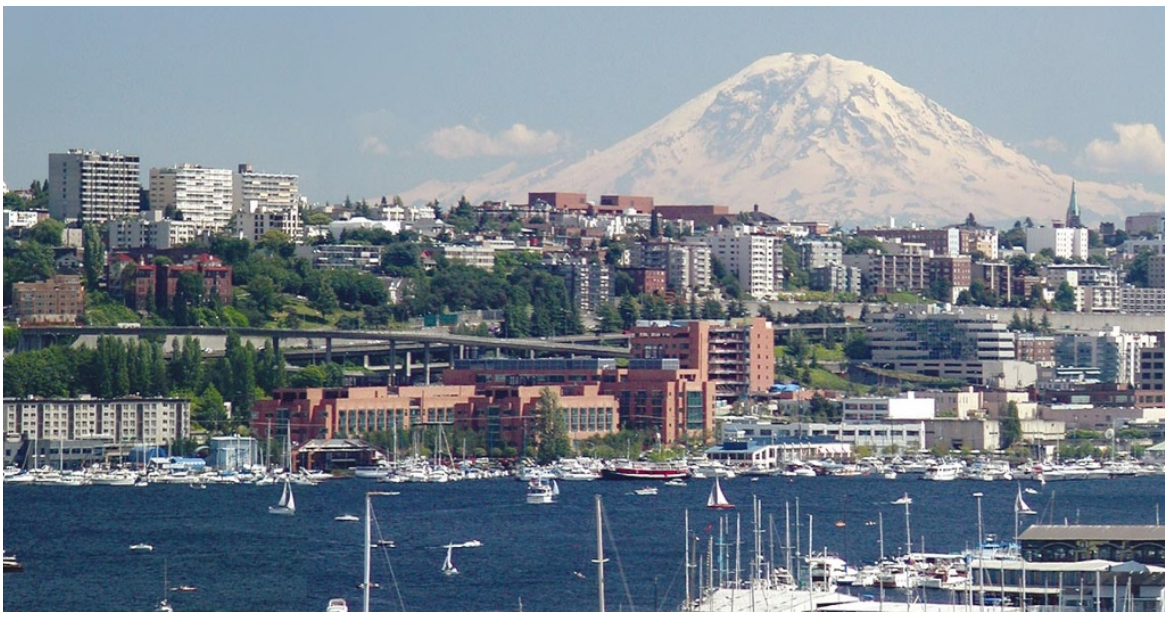

Under attack: the Fred Hutchinson Cancer Research Center was heavily criticized by The Seattle Times.

board set to announce the prizewinners on 8 April, The Wall Street Journal has launched what observers say is an unprecedented attack on The Seattle Times series.

\section{Foresters cautious over transgenics}

Virginia Gewin, Washington

American farmers may have jumped at the chance to use genetically modified crops, but foresters are set to take a more cautious approach.

That is the main message of a report on genetically engineered trees just published by the Washington-based Pew Initiative on Food and Biotechnology.

Forest biotechnology has the potential to create pest-resistant trees, to design trees for more easily processed wood products, and possibly to restore endangered species.

But environmental, regulatory and societal issues, which have been problematic for agriculture, could spell more trouble for forestry, says the report, which was written on the basis of a conference run by the Pew Initiative in December. Because trees can spread their pollen over long distances, and plantations are often close to natural forests, gene flow into wild populations would be inevitable, the report says.

The meeting was co-sponsored by the Society of American Foresters (SAF) and the Ecological Society of America, and sought to bring ecologists and foresters together to identify key issues in the debate. Such issues include risk assessment, public participation in decision-making, and possible changes to regulatory oversight of forest biotechnology.

"You just can't afford to make an investment in forestry that's too risky, because it takes so long for the trees to grow," says Terry Clark, science manager with SAF.

But Toby Bradshaw, a forestry expert at the University of Washington in Seattle, says that transgenics will be important in forest research even if it is not used in commercial forestry.

The Pew Initiative hopes to take recommendations for improving US policies and programmes related to forest biotechnology to Congress by this autumn.
The episode recalls this year's Oscar fight, when Hollywood studios blamed reporters for running a smear campaign against the film A Beautiful Mind. But although the Oscars are known for inspiring massive lobbying crusades, journalists say that they have never seen anything like this unruly Pulitzer squabble.

The battle began on 19 March, when Laura Landro wrote an opinion column in The Wall Street Journal slamming "Uninformed consent". Landro, an assistant managing editor at The Wall Street Journal, called the series "fundamentally false".

"Rather than racking up prizes, it should be used as a textbook case on how the media can convey biased and misleading information about biomedical research," Landro wrote.

Landro noted, for example, that the Hutchinson centre was one of the first cancer centres in the world to acknowledge problems with a trial involving the removal of $\mathrm{T}$ cells from bone marrow donated in transplants, when problems caused by the removal became known.

Michael Fancher, executive editor of The Seattle Times, leapt to his paper's defence on 22 March. He accused Landro of failing to disclose her own conflict of interest. Fancher said that Landro had donated money to the Hutchinson centre, widely nicknamed 'the 
Hutch', after she was successfully treated there in 1992.

"Unfortunately, Ms. Landro is unable to separate her own experience as a patient from her duties as a journalist," Fancher wrote in The Seattle Times.

From there, the tussle escalated, even though editors at both papers say that The Wall Street Journal is not competing with "Uninformed consent" for a Pulitzer in the investigative reporting category.

On 25 March, The Wall Street Journal published a letter from Fancher in which he accused the Hutch of failing to enact reforms of its clinical-trials oversight process that had been recommended by a review committee. He also said the Food and Drug Administration had found problems with the centre's informedconsent process and shut down three clinical trials there in June 2001.

The Wall Street Journal then devoted an unsigned editorial to an attack on "Uninformed consent" on 27 March. The editorial accused The Seattle Times of sexism and ambulance-chasing. It implied that the paper had not published a previous letter from Landro because the letter would have had to be included in the Pulitzer submission. It also ran a series of letters from scientists and doctors criticizing The Seattle Times series.

On The Wall Street Journal's editorial page, editors claimed that far more is at stake than just a prize for journalists. "We have long felt that medical research needs to be liberated, not inhibited," they wrote.

Some science journalists say that they are concerned that The Seattle Times series was not as thorough or as scientifically rigorous as it should have been.

B. D. Colen, winner of a Pulitzer Prize and faculty member of the graduate programme in science writing at the Massachusetts Institute of Technology, says that the first instalment of the series did not give complete information about the different stages of clinical research, or where the Hutch's experiments fitted into these stages.

But despite the criticism levelled at the series, some observers are defending it on the grounds that the award of the Pulitzer would encourage more investigative reporting into science and medicine.

Another Pulitzer winner, Deborah Blum, president-elect of the National Association of Science Writers, says that she has not read the series. But she welcomes it, saying that there is too little investigative journalism into science and medicine.

"It does not bother me at all that a local newspaper made a cancer centre angry in its investigation," Blum says. "Especially with clinical trials, it's such a good thing to get inside them and try to make people understand what they are about."

\section{Online tumour bank aims to offer ready route to tissues}

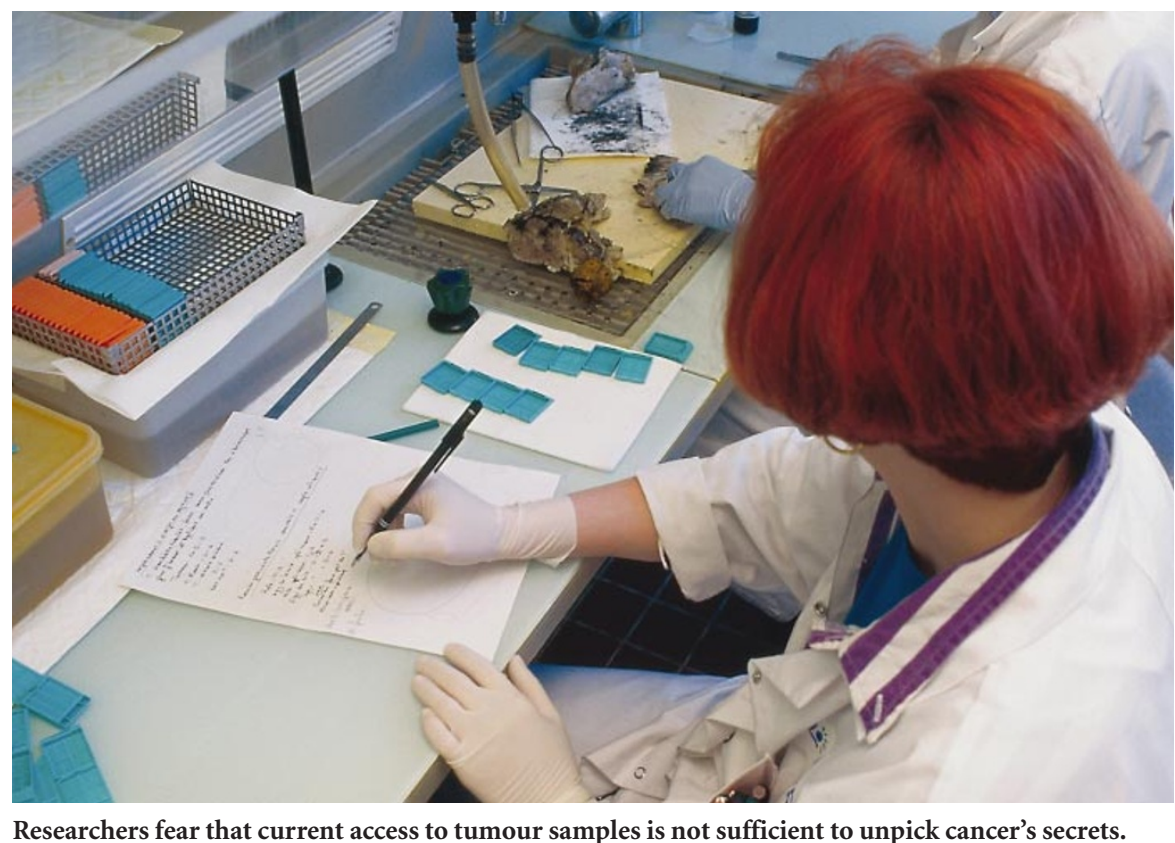

David Adam, London

It is a pathological paradox: how to meet cancer researchers' increasing demand for human tissue while public concern about its use reduces the amount available.

Last week the European Organisation for Research and Treatment of Cancer (EORTC) unveiled its solution - an online library of tens of thousands of tumour tissue samples held at research centres and tissue banks across Europe.

Under plans discussed at last month's EORTC conference in Brussels, participating researchers would browse through samples online and take enough tissue and associated clinical data to carry out molecular profiling and clinical trials. The frozen samples would be stored at the respective centres, and a representative section then scanned and entered into the virtual library.

"By making more tissue more easily available to scientists we can speed up translational research tremendously," says Wolter Oosterhuis, a pathologist at University Hospital Rotterdam who is leading the project.

An increase in both regulation and public scrutiny of the use of research tissue is making access to some materials increasingly difficult. Nick Lemoine, a cancer researcher at London's Hammersmith Hospital, says that supplies of tissue "almost dried up" in some parts of Britain following a series of high-profile scandals over retention of human tissue without consent. Others say that a shortage of pathologists and a tendency to take smaller amounts of material during each biopsy have made some tumour tissue harder to obtain.
The plans are at an early stage, but Oosterhuis is hopeful that the system can be up and running within four years. It builds on a similar EORTC initiative to digitize thousands of slides of tissue samples to create a virtual tumour-tissue bank. Such slides allow physical comparison between samples, but fresh tissue is more useful as it allows investigation of DNA, RNA and protein expression, which researchers believe will shed light on genetic contributions to cancer (see page 470).

Eight cancer centres in France, the Netherlands, Spain, Austria and Britain have signed up to the scheme, although some centres have refused to take part. "Scientists are not easily separated from their materials," Oosterhuis says, "but we argue that by making it available to others you get access to many more samples than you can ever collect yourself.'

The move comes as some researchers express concern that the existing network of tissue banks cannot meet the growing demand for materials. "There has been a huge expansion of molecular analysis on the basis of the genome and we need to provide the materials for this tissue analysis to be done," says Mike Stratton, who heads the Cancer Genome Project at Britain's Sanger Centre near Cambridge.

Some countries, such as the United States and Spain, already link the contents of local banks into a national network. Others are setting up centralized national facilities for tumour tissue. In Britain, a generic tumourtissue bank that will ultimately contain some 3,000 samples from 23 different cancers is expected to open at the University of Glasgow by the end of this year. 